\title{
A mapping of nursing and midwifery research in the Eastern Mediterranean Region, 2006-2016
}

Huda Abu-Saad Huijer, ${ }^{1}$ Hiba Deek ${ }^{1}$ and Samar Noureddine ${ }^{1}$

${ }^{1}$ Hariri School of Nursing, American University of Beirut, Beirut, Lebanon (Correspondence to: Huda Abu-Saad Huijer: huda.huijer@aub.edu.lb).

\begin{abstract}
Background: Nurses and midwives constitute the largest group of health care professionals globally. Challenges to these professions make it difficult to set regional priorities for policies and research development.

Aims: The purpose of this study was to map current nursing and midwifery research in the Eastern Mediterranean Region.

Methods: Nursing and midwifery schools were identified by each country's nursing and midwifery board and ministries of education/public health. Information was collected for the years 2006-2016 via surveys, websites, Google scholar and expert informants.

Results: A total of 299 schools were identified and 241 of these were contacted; 85 completed surveys from 15 countries were analysed. A total of 1116 research topics covered by 3287 publications were identified, many of which were clustered into the five World Health Organization priority areas. The least developed areas were disaster management and emergency preparedness.

Conclusions: This study provides a database of nursing and midwifery research in the Region. Some gaps were identified based on the research priorities of the Region, but these gaps could be addressed by close collaboration among local researchers.
\end{abstract}

Keywords: nursing; midwifery; research; regional priorities \& development; Eastern Mediterranean Region

Citation: Abu-Saad Huijer H; Deek H; Noureddine S. A mapping of nursing and midwifery research in the Eastern Mediterranean Region, $2006-2016$. East Mediterr Health J. 2018;24(9):888-898. https://doi.org/10.26719/2018.24.9.888

Received: 02/10/17; accepted: 20/03/18

Copyright (C) World Health Organization (WHO) 2018. Some rights reserved. This work is available under the CC BY-NC-SA 3.0 IGO license (https:// creativecommons.org/licenses/by-nc-sa/3.o/igo).

\section{Introduction}

\section{Background}

Nurses and midwives constitute the largest group of health care professionals globally (1). Their credentials and experience impact their ability to respond to health care crises (2). The shortage of nurses combined with political instability and man-made disasters in the World Health Organization (WHO) Eastern Mediterranean Region have hindered their development $(3,4)$. The critical role of these professions and the challenges they face are recognized by WHO as major strategic goals (1).

The Eastern Mediterranean Region is one of the six WHO regions. It is a diverse region of Arab and non-Arab countries, with varying levels of socioeconomic, political and demographic development, and can be divided into three country groups $(5,6)$ : Group 1 comprises countries with high income following four decades of continuous socioeconomic development; Group 2 comprises middleincome countries; and group 3 comprise countries of limited resources and low income (3). Each group of countries has its own particular features and challenges in terms of health, politics, economy and culture. A recent review showed the leading causes of mortality and disability in Arab countries to be: ischaemic heart disease, stroke, lower respiratory infections, diarrheal diseases, diabetes, road injuries, cirrhosis, preterm birth complications, hypertensive heart disease, congenital anomalies, major depressive disorder and chronic kidney disease (5). The characteristics and the spread of these diseases directly impact the nursing and midwifery professions, especially in areas of high deployment and shortages.

\section{Nursing and midwifery in the Region}

Nurses and midwives are the front line health care professionals in times of natural and man-made disasters. Their practice, both in the hospital setting and in the community, enhances patient outcomes, promotes and maintains well-being and directly impacts morbidity and mortality (6). Therefore, appropriate numbers of qualified nurses and midwives in the right places with appropriate resources are crucial to maintaining successful health care systems (2). The Global Strategic Directions for Strengthening Nursing and Midwifery 2016-2020 vision statement is: "Accessible, available, acceptable, quality and cost-effective nursing and midwifery care for all, based on population needs, in support of universal health coverage and the Sustainable Development Goals"(7).

However, these goals can only be adequately met when challenges related to work environment, human resources, education, research and regulations are 
overcome. More attention to that effect needs to be focused on lack of resources, shortage of qualified professionals, poor access to quality education, lack of research dissemination, lack of regulations and in some cases absence of regulatory bodies (8-11).

A meeting was held in Jordan in 2015 with nursing and midwifery officers and stakeholders to discuss these challenges. The lack of in-depth knowledge of the status of the professions was the key finding, highlighting the need for research in the Region covering each country group. The first step suggested was to develop a national database on the current status of the professions and research activities in the Region (12).

\section{Research activity}

There is limited research activity in the Region due to the lack of researchers and resources and poor dissemination of research results, which leads to poor impact on national policies and practices (13). Continuous and vigorous research is a necessity in this complex and highly variable health care context. Conducting research will not only identify gaps in practice but will also reveal new approaches suitable for the care of patients with distressing chronic conditions (14). As one of its priorities, the framework for action, Strengthening Nursing and Midwifery in the Region 2015-2025, emphasized the importance of conducting research and translating its outcomes into practice, education and service development (15).

Choosing research topics should be based on national and regional health needs, resource availability and the financial benefits associated with conducting and translating the proposed research studies (16). The research policy and development programme established by WHO encourages the conduct of health research in the Region by providing assistance and connecting regional and international health research agencies (16). There has been an agreement on research priorities for the Region; these are continually discussed in regional meetings (16), including meetings of the Advisory Committee on Health Research (13), and are the basis of regional calls for research proposals (16). The priorities are: strengthening the health care systems; maternal, reproductive and child health and nutrition; noncommunicable diseases; communicable diseases; and emergency preparedness.

These research priorities arise from the current health challenges faced in the Region, communicable and noncommunicable disease surveillance, health promotion, health systems, prevention and access to health care, in addition to maternal and child health, mental health and substance abuse, and disasters and emergencies (3). However, although these topics may seem pressing in many areas of this Region, there is limited evidence of the current research activity covering them: with poor documentation, gaps in research cannot be identified. The purpose of this study was to identify the current nursing and midwifery research in the WHO Eastern Mediterranean Region and to assess possibilities for research collaboration.

\section{Methods}

Information on nursing and midwifery research for the period 2006-2016 was gathered through contacts with nursing and midwifery regulatory bodies of the 22 countries of the Region (board, federation, order and council), the ministries of higher education and public health, and from the Scientific Society of Arab Nursing Faculties.

The methods used for data collection included a thorough search of nursing and midwifery schools. Surveys were emailed to the deans for data regarding their PhD-holder faculty. These surveys were provided in Arabic, English and French and asked about the number of PhD-holder faculty members in each faculty or department, and their list of publications in the last 10 years, in addition to the exact names of the university and the school/faculty for easier archiving and clustering. Three reminder emails were sent at 2-week intervals. Concurrently, the same data were obtained from schools of nursing and midwifery in the 22 countries using a web-based search. These schools were identified from the Scientific Society of Arab Nursing Faculties website (15 countries) or by Google search and the websites of the respective ministries in each country. Starting with the names of universities, then nursing faculties or departments, we searched for the names of PhD-holder faculty members on the school's website and their research activities; those with no publications listed on the university websites were searched for on Google Scholar for possible retrievals. These publications were then matched with the country and university names under study to ensure accuracy of information. The information obtained by survey and web search for each participating school was examined and duplicates eliminated prior to the analysis. When duplicates were found, data obtained from the surveys were prioritized over those extracted from the web-based search. Data collection was done between July and the end of September 2016.

All data collected from surveys and websites were entered into SPSS, version 24, to generate a list of research topics. The list was then analysed qualitatively by authors to develop themes that fall under the research priorities of the Region. We analysed these themes by country and then collectively by providing the frequency of publications per theme. Frequencies and percentages were used for analysis. The data, including the complete list of publications, are housed at the American University of Beirut, where the research study was conducted in collaboration with the WHO Regional Office for the Eastern Mediterranean.

\section{Results}

\section{Schools}

During the 3-month study period (July-September, 2016), 299 nursing and midwifery schools were identified in the 22 countries of the Region. Out of these, 241 (80.6\%) were accessed via email. The remaining ones either had no ac- 
cessible email addresses, or emails could not be delivered to their addresses.

The response rate was $35 \%$, with 85 surveys received from 15 countries. The completed surveys represented 41 out of 241 (17\%) schools as follows: Bahrain (1), Egypt (2), Islamic Republic of Iran (5), Iraq (3), Jordan (4), Lebanon (7), Pakistan (1), Palestine (6), Saudi Arabia (2), Somalia (3), Sudan (6) and United Arab Emirates (1).

Data on publications were sought from the remaining 44 schools $(18 \%)$ by web search as follows: Egypt (7), Islamic Republic of Iran (6), Iraq (1), Jordan (8), Lebanon (1), Oman (1), Pakistan (16), Palestine (1), Qatar (1), Sudan (1) and Yemen (1).

The following countries could not be reached at all despite repeated reminders: Afghanistan, Djibouti, Kuwait, Libya, Morocco, Syrian Arab Republic and Tunisia.

The majority of the collected data came from nursing schools $(\mathrm{n}=72$; $82 \%$ ); while only 13 surveys $(15 \%)$ came from nursing and midwifery schools from four countries (Table 1).

Data on faculty members were provided by 80 schools out of the 85 included (derived from both returned surveys and web-based search). Only 61 schools (71.7\%) had PhDholder faculty (range 1-136, mean 11.2). All the returned surveys included complete faculty publication details. However, a web-based search of the 44 schools revealed only $25(56.8 \%)$ with publications available online.

\section{Research themes and categories}

We extracted 1116 nursing and midwifery research topics. These were then clustered under the 5 themes identified as research priorities in the Region: communicable diseases, noncommunicable diseases, health systems, maternal and child health and disaster management. Other topics that did not fit under these themes were categorized separately as nursing education, pain relief and palliative care, psychometric evaluation, older adult health and population health. The main themes were further divided into detailed categories to capture more topics. The categories under noncommunicable diseases included: cancer, cardiovascular disease, neurological disease, diabetes, respiratory disease, kidney disease and mental illness. Communicable diseases were categorized as infectious disease and infection control studies. Health systems research included topics such as nursing and midwifery workforce, job satisfaction, retention, patient safety and electronic patient records. Maternal and child health included topics such as pregnancy and childbirth, contraception, family planning, counselling, complications, postpartum depression, neonatal care and paediatric intensive care. The total number of publications retrieved was 3287, distributed according to WHO research priorities as follows: noncommunicable diseases 692 (21.0\%); maternal and child health $836(25.4 \%)$, health systems $645(19.6 \%)$; communicable diseases $155(4.7 \%)$ and disaster management $30(0.1 \%)$.

The research themes were then clustered by country.
Table 1 Nursing and midwifery schools $(n=85)$ in the WHO Region for the Eastern Mediterranean covered in the survey, 2016

\begin{tabular}{|c|c|c|}
\hline \multirow[t]{2}{*}{ Country } & \multicolumn{2}{|c|}{ No. of schools } \\
\hline & Nursing & $\begin{array}{l}\text { Nursing \& } \\
\text { midwifery }\end{array}$ \\
\hline Bahrain $^{\mathrm{a}}$ & 1 & - \\
\hline Egypt & 9 & - \\
\hline Islamic Republic of Iran & 3 & 8 \\
\hline Iraq & 4 & - \\
\hline Jordan & 12 & - \\
\hline Lebanon & 7 & 1 \\
\hline Oman $^{b}$ & 1 & - \\
\hline Pakistan & 16 & 1 \\
\hline Palestine & 7 & - \\
\hline Qatar ${ }^{\mathrm{b}}$ & 1 & - \\
\hline Saudi Arabia ${ }^{a}$ & 2 & - \\
\hline Somalia $^{a}$ & 0 & 3 \\
\hline Sudan & 7 & - \\
\hline United Arab Emirates ${ }^{a}$ & 1 & - \\
\hline Yemen $^{\mathrm{b}}$ & 1 & - \\
\hline Total & 72 & 13 \\
\hline
\end{tabular}

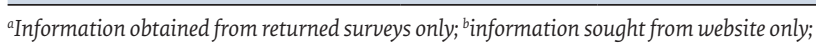
all other data were obtained from both surveys and websites.

Significantly, all the themes were addressed by four countries only: Egypt, Islamic Republic of Iran, Jordan and Lebanon; Iraq, however, addressed all five research priorities. The majority of the countries addressed communicable diseases, noncommunicable diseases, maternal and child health and health systems, which are all research priorities for the Region. Additionally, most countries had publications that addressed nursing education, which does not fall under these priorities.

Table 2 shows the numbers of publications identified within the research themes in the countries of the Region. The total of 3287 publications included 692 on noncommunicable diseases, 836 on maternal and child health, 645 on health systems and 376 on nursing education. In the Islamic Republic of Iran, Tehran, Shiraz, Tabriz and Islamic Republic of Iran universities of medical sciences conducted research in all the research themes and their categories. Jordan University of Science and Technology reported research in all areas except for older adult health, while the University of Jordan had publications in all areas. In Egypt, Cairo University reported research on all themes except for population health and older adult health while the University of Alexandria has publications in all research areas. Aga Khan University in Pakistan reported research in all areas except for older adult health. In Lebanon, the American University of Beirut published in most noncommunicable disease areas, as well as health systems, communicable diseases and maternal and child health, with few studies in disaster and emergency management. Regarding research that does not fall within the WHO priorities, 
Table 2 Publications from universities in the countries of the Eastern Mediterranean Region during the period 2006-2016 $(n=$ 3287) grouped according to health topic

\section{Country University (No.)}

Noncommunicable diseases $(n=692)$

Bahrain

Egypt

Royal College of Surgeons in Ireland (RCSI) Medical University of Bahrain (21)

Egpt

Cairo University (27)

University of Alexandria (17)

Islamic Republic of Iran

Tanta University (22)

Tehran University (54)

Shiraz University (53)

Tabriz University of Medical Sciences (120)

Iran University of Medical Sciences (57)

Mashhad University School of Nursing and Midwifery (7)

Iraq

Babylon University (17)

Hawler University (2)

Baghdad University (6)

Sulaimani University (1)

Jordan

Zarqa University (13)

$\mathrm{Al}$ Al-Bayt University (4)

Jordan University of Science and Technology (42)

Zeytouna University (24)

Applied Science Private University (14)

The University of Jordan (82)

Lebanon

American University of Beirut (45)

Lebanese American University (7)

Université Saint-Joseph (1)

Lebanese University (4)

Oman

Sultan Qaboos University (6)

Pakistan

Aga Khan University (10)

Palestine

Al-Najah National University (11)

The Arab American University Jenin (7)

Al-Azhar University-Gaza (2)

Birzeit University (1)

Qatar

University of Calgary in Qatar (3)

Saudi Arabia

King Saud Bin Abdul Aziz University for Health Sciences (KSA) College of Nursing, Jeddah (1)

Sudan

Nahda College (1)

Khartoum University (5)

United Arab Emirates

University of Sharjah (5)

\section{Maternal and child health $(n=836)$}

Bahrain

RCSI Medical University of Bahrain (1)

Egypt

Cairo University (24)

University of Alexandria (17)

Tanta University (60)

Islamic Republic of Iran

Tehran University (36)

Shiraz University (38)

Mashhad School of Nursing Midwifery (15)

Tabriz University of Medical Sciences (260)

Iran University of Medical Sciences (44)

Iraq

Babylon University (15)

Baghdad University (9)

Sulaimani University (4)

Jordan

University of Jordan (52)

Zarqa University (4)

Al Al-Bayt University (15)

Jordan University of Science and Technology (76)

Applied Science Private University (20)

Zeytouna University (6)

Lebanon

University of Balamand (11)

American University of Beirut (12)

Lebanese University (9)

Lebanese American University (3)

Oman

Sultan Qaboos University (10)

Pakistan

Aga Khan University (18) 
Table 2 Publications from universities in the countries of the Eastern Mediterranean Region during the period 2006-2016 $(n=$ 3287) grouped according to health topic (continued)

\section{Country}

Palestine

Sudan

Arab Emirates

Health systems $(n=645)$

Bahrain

Egypt

Islamic Republic of Iran

Jordan

Pakistan

Palestine

\section{Iraq}

\section{University (No.)}

The Arab American University Jenin (5)

Al-Najah National University (4)

Al-Azhar University - Gaza (2)

Birzeit University (19)

Ibn Sina College (1)

College of Nursing Jeddah (1)

Nahda College (1)

Khartoum University (2)

Bahri University (1)

Al-Neelain University (4)

Sudan University of Medical Science and Technology (2)

University of Sharjah (7)

RCSI Medical University of Bahrain (21)

Cairo University (6)

University of Alexandria (33)

Tanta University (21)

Tehran University (89)

Shiraz University (33)

Mashhad School of Nursing Midwifery (4)

Tabriz University of Medical Sciences (85)

Iran University of Medical Sciences (66)

Babylon University (6)

Hawler University (1)

Sulaimani University (1)

Baghdad University (3)

The University of Jordan (56)

Al Al-Bayt University (6)

Jordan University of Science and Technology (42)

Zeytouna University (6)

Applied Science Private University (29)

Zarqa University (5)

American University of Beirut (39)

Lebanese University (3)

Lebanese American University (4)

University of Balamand (2)

Université Saint-Joseph (4)

Sultan Qaboos (6)

Aga Khan University (38)

The Arab American University Jenin (4)

Hebron University (6)

Al-Najah National University (2)

Al-Azhar University - Gaza (1)

Birzeit University (5)

Saudi Arabia

College of Nursing Jeddah (6)

Sudan

Bahri University (1)

Al-Neelain University (1)

Sudan University of Medical Science and Technology (1)

Nahda College (1)

Khartoum University (2)

United Arab Emirates

University of Sharjah (4)

Yemen

Sanaa University (2)

\section{Communicable diseases $(n=155)$}

Bahrain

RCSI Medical University of Bahrain (11)

Egypt

Cairo University (2)

University of Alexandria (2)

Tanta University (7)

Islamic Republic of Iran

Tehran University (5)

Shiraz University (5)

Tabriz University of Medical Sciences (19)

Iran University of Medical Sciences (5) 
Table 2 Publications from universities in the countries of the Eastern Mediterranean Region during the period 2006-2016 $(n=$ 3287) grouped according to health topic (continued)

\section{Country}

University (No.)

\begin{tabular}{|c|c|}
\hline Iraq & Babylon University (50) \\
\hline Jordan & $\begin{array}{l}\text { The University of Jordan (4) } \\
\text { Applied Science Private University (4) } \\
\text { Jordan University of Science and Technology (6) }\end{array}$ \\
\hline Lebanon & $\begin{array}{l}\text { American University of Beirut (3) } \\
\text { Lebanese University (5) } \\
\text { Lebanese American University (1) }\end{array}$ \\
\hline Oman & Sultan Qaboos University (10) \\
\hline Pakistan & Aga Khan University (9) \\
\hline Palestine & Arab American University Jenin (1) \\
\hline Saudi Arabia & College of Nursing Jeddah (2) \\
\hline Sudan & Nahda College (2) \\
\hline Yemen & Sana’a University (2) \\
\hline \multicolumn{2}{|c|}{ Disaster management $(n=30)$} \\
\hline Bahrain & RCSI Medical University of Bahrain (3) \\
\hline Egypt & Tanta University (2) \\
\hline Islamic Republic of Iran & $\begin{array}{l}\text { Tehran University (3) } \\
\text { Shiraz University (2) } \\
\text { Tabriz University (5) } \\
\text { Iran University of Medical Sciences (1) }\end{array}$ \\
\hline Iraq & $\begin{array}{l}\text { Babylon University (1) } \\
\text { Hawler University (1) } \\
\text { Baghdad University (3) }\end{array}$ \\
\hline Jordan & $\begin{array}{l}\text { The University of Jordan (2) } \\
\text { Jordan University of Science and Technology (2) } \\
\text { Applied Science Private University (3) }\end{array}$ \\
\hline Lebanon & American University of Beirut (7) \\
\hline Pakistan & Aga Khan University (1) \\
\hline Palestine & The Arab American University Jenin (1) \\
\hline United Arab Emirates & University of Sharjah (1) \\
\hline \multicolumn{2}{|c|}{ Nursing education $(n=376)$} \\
\hline Egypt & $\begin{array}{l}\text { Cairo University (27) } \\
\text { Tanta University (6) } \\
\text { University of Alexandria (15) }\end{array}$ \\
\hline Islamic Republic of Iran & $\begin{array}{l}\text { Tehran University (42) } \\
\text { Shiraz University (30) } \\
\text { Mashhad School of Nursing Midwifery (3) } \\
\text { Tabriz University of Medical Sciences (91) } \\
\text { Iran University of Medical Sciences (26) }\end{array}$ \\
\hline Lebanon & $\begin{array}{l}\text { American University of Beirut (11) } \\
\text { Lebanese University (1) } \\
\text { Lebanese American University (5) } \\
\text { Beirut Arab University (1) } \\
\text { University of Balamand (1) } \\
\text { Université Saint-Joseph (1) }\end{array}$ \\
\hline Oman & Sultan Qaboos University (7) \\
\hline Pakistan & Aga Khan University (25) \\
\hline Palestine & $\begin{array}{l}\text { Al-Najah National University (2) } \\
\text { Birzeit University (1) } \\
\text { The Arab American University Jenin (2) } \\
\text { Hebron University (2) }\end{array}$ \\
\hline Saudi Arabia & $\begin{array}{l}\text { Ibn Sina College (1) } \\
\text { KSA College of Nursing Jeddah (5) }\end{array}$ \\
\hline United Arab Emirates & University of Sharjah (1) \\
\hline Yemen & Sana’a University (2) \\
\hline
\end{tabular}


Table 2 Publications from universities in the countries of the Eastern Mediterranean Region during the period 2006-2016 $(n=$ 3287) grouped according to health topic (continued)

\section{Country}

University (No.)

Pain relief and palliative care $(n=102)$

\begin{tabular}{|c|c|}
\hline Egypt & $\begin{array}{l}\text { Cairo University (2) } \\
\text { Tanta University (1) } \\
\text { University of Alexandria (3) }\end{array}$ \\
\hline Islamic Republic of Iran & $\begin{array}{l}\text { Tehran University (7) } \\
\text { Shiraz University (6) } \\
\text { Tabriz University of Medical Sciences (13) } \\
\text { Iran University of Medical Sciences (6) }\end{array}$ \\
\hline Iraq & Hawler University (1) \\
\hline Jordan & $\begin{array}{l}\text { The University of Jordan (13) } \\
\text { Zarqa University (1) } \\
\text { Al Al-Bayt University (1) } \\
\text { Applied Science Private University (1) } \\
\text { Jordan University of Science and Technology (5) }\end{array}$ \\
\hline Lebanon & $\begin{array}{l}\text { American University of Beirut (30) } \\
\text { Lebanese American University (6) }\end{array}$ \\
\hline Oman & Sultan Qaboos University (1) \\
\hline Pakistan & Aga Khan University (1) \\
\hline Palestine & The Arab American University Jenin (3) \\
\hline United Arab Emirates & University of Sharjah (1) \\
\hline \multicolumn{2}{|c|}{ Population health $(n=284)$} \\
\hline Egypt & University of Alexandria (8) \\
\hline Islamic Republic of Iran & $\begin{array}{l}\text { Tehran University (21) } \\
\text { Shiraz University (15) } \\
\text { Mashhad School of Nursing Midwifery (5) } \\
\text { Tabriz University of Medical Sciences (67) } \\
\text { Iran University of Medical Sciences (21) }\end{array}$ \\
\hline Iraq & $\begin{array}{l}\text { Babylon University (5) } \\
\text { Hawler University (2) }\end{array}$ \\
\hline Jordan & $\begin{array}{l}\text { The University of Jordan (53) } \\
\text { Zarqa University (4) } \\
\text { Al Al-Bayt University (5) } \\
\text { Jordan University of Science and Technology (29) } \\
\text { Applied Science Private University (2) }\end{array}$ \\
\hline Lebanon & $\begin{array}{l}\text { American University of Beirut (11) } \\
\text { Lebanese University (4) } \\
\text { Lebanese American University (3) }\end{array}$ \\
\hline Oman & Sultan Qaboos University (3) \\
\hline Pakistan & Aga Khan University (18) \\
\hline Palestine & $\begin{array}{l}\text { Birzeit University (3) } \\
\text { Hebron University (4) } \\
\text { Al-Azhar University-Ghaza (1) }\end{array}$ \\
\hline \multicolumn{2}{|l|}{ Older adult health $(n=63)$} \\
\hline Bahrain & RCSI Medical University of Bahrain (2) \\
\hline Egypt & $\begin{array}{l}\text { University of Alexandria (10) } \\
\text { Tanta University (1) }\end{array}$ \\
\hline Islamic Republic of Iran & $\begin{array}{l}\text { Tehran University (9) } \\
\text { Shiraz University (8) } \\
\text { Tabriz University of Medical Sciences (10) } \\
\text { Iran University of Medical Sciences (6) }\end{array}$ \\
\hline Iraq & $\begin{array}{l}\text { Babylon University (1) } \\
\text { Baghdad University (2) } \\
\text { Sulaimani University (1) }\end{array}$ \\
\hline Jordan & $\begin{array}{l}\text { The University of Jordan (3) } \\
\text { Al Al-Bayt University (1) }\end{array}$ \\
\hline Lebanon & $\begin{array}{l}\text { American University of Beirut (1) } \\
\text { Université Saint-Joseph (6) }\end{array}$ \\
\hline Qatar & University of Calgary (1) \\
\hline United Arab Emirates & University of Sharjah (1) \\
\hline
\end{tabular}




\begin{tabular}{|c|c|}
\hline Country & University (No.) \\
\hline Psychometric evaluation & \\
\hline Bahrain & RCSI Medical University of Bahrain (2) \\
\hline Egypt & $\begin{array}{l}\text { Cairo University (1) } \\
\text { University of Alexandria (1) }\end{array}$ \\
\hline Islamic Republic of Iran & $\begin{array}{l}\text { Tehran University (13) } \\
\text { Shiraz University (8) } \\
\text { Tabriz University of Medical Sciences (15) } \\
\text { Iran University of Medical Sciences (9) }\end{array}$ \\
\hline Iraq & Baghdad University (1) \\
\hline Jordan & $\begin{array}{l}\text { The University of Jordan (22) } \\
\text { Jordan University of Science and Technology (10) } \\
\text { Zeytouna University (3) } \\
\text { Applied Science Private University (1) }\end{array}$ \\
\hline Lebanon & $\begin{array}{l}\text { American University of Beirut (6) } \\
\text { Lebanese University (2) } \\
\text { Lebanese American University (2) }\end{array}$ \\
\hline Pakistan & Aga Khan University (5) \\
\hline Palestine & Al-Najah National University (1) \\
\hline
\end{tabular}

most of the surveyed schools reported publications in nursing education, but few reported publications specifically addressing older adult health.

\section{Discussion}

The aim of this study was to identify the research topics covering nurses and midwives in the WHO Eastern Mediterranean Region and compare them under the research priorities identified by the WHO Regional Office. This research would then facilitate collaboration between countries with similar research interests. Surveys were sent to nursing and midwifery schools and web-based searches were conducted to address these aims. The low response rate may be attributable to the unstable war conditions in Afghanistan, Djibouti, Iraq, Libya, Syrian Arab Republic and Yemen. Other reasons for the low response rate could be the lack of university level nursing and midwifery education or the limited number of PhD-prepared faculty and staff active in research in some of the countries, as may be the case in schools of nursing that are departments within bigger faculties, e.g. medicine or pharmacy, which do not encourage nursing research. Another reason may be the heavy teaching load or lack of funding for research. Our study did not address this issue but it is worth pursuing in future research.

The most studied research topics are in communicable and noncommunicable diseases. Chronic obstructive pulmonary disease and mental health problems were the least studied among the noncommunicable diseases. These findings are surprising considering the high smoking rates and the high prevalence of dementia and Alzheimer's disease in the Region $(17,18)$. Although research on nursing and midwifery education is not one of the WHO research priorities listed by the Advisory Committee on Health Research in its meeting in Egypt in 2014 (19), it was a topic of research interest in the Region.
This could be due to the easier access to study subjects (i.e. students), available resources in universities and the relative ease of conducting such research activity compared with clinical research, where patients are targeted. Additionally, and despite the high numbers of women and children refugees in these countries (15), there is a limited number of studies addressing their needs: even though there are millions of refugees and displaced persons in the Region, we identified only 3 publications addressing refugee health.

Other topics of interest are those on health systems such as health policy, quality management, nursing and midwifery workforce and patient satisfaction, which are commonly conducted in hospital settings but are almost absent in community settings, including refugee camps. One topic that has received some attention in the Region is the nursing and midwifery workforce. Job satisfaction, retention and migration of personnel are common concerns in all countries and are reflected in the research activity $(8,20,21)$. Research addressing the effectiveness of solutions that tackle the above concerns is highly needed. Possible solutions could include the inclusion of an advanced scope of practice for nurses and midwives including those in remote and rural areas, thus enhancing their autonomy and recognizing their valuable contribution to health care delivery in the countries of the Region.

The least studied research topics are disaster management and emergency preparedness. This finding is similar to the results of a recent scoping review of research in nursing and midwifery (19), where no study on disaster and emergency preparedness was identified. The need for research on such topics is pressing in view of the current regional turmoil and instability due to wars and the high influx of refugees. The roles of nurses in disaster management and emergency preparedness 
need to be addressed and more rigorously studied.

Looking at research areas in universities, it becomes clear that there is shared expertise across many countries and schools of nursing. The potential for collaboration and networking to advance the state of research is great. The next step would be to identify specific investigators with similar research interests and develop a network to encourage them to collaborate in research. One initiative in this direction is a database that was developed by the University of Jordan Faculty of Nursing that includes publications by all nursing faculty members in Jordan since 1986. It can be searched by name or topic or even research design. The site can be accessed at http://jdnr. ju.edu.jo/home.aspx. Publications by Jordanian nurse researchers and students that were conducted outside Jordan are also included in this database. Other countries may follow suit and develop their own database. However, this endeavour may be taxing and would be better coordinated by a central body. Other initiatives that feed into promoting nursing research and networking in the Region include a Delphi survey conducted by Columbia University that identified research priorities from the perspective of nurse leaders (22). The findings of these studies will provide further insight into the gaps in this regard.

The limitations of the study include the low response rate and the lack of research information provided on university websites, thus publications may have been missed. Our research findings could have been richer and more comprehensive with greater data return.

\section{Recommendations}

In this study, nursing and midwifery research topics were identified, which will facilitate networking and collaboration among nurse and midwifery researchers of the Region.

The following recommendations can be made.

- University websites need to be updated with faculty research activity, interests and publications.

- A database of the research activity in the Region could be established and regularly updated based on WHO research priorities.

- The website of the Scientific Society of Arab Nursing Faculties needs to be updated to include current research output of member schools.

- Nursing and midwifery researchers should be encouraged to network with other researchers and make their research activities more visible through free websites such as ResearchGate, Google Scholar, etc.

Funding: None.

Competing interests: None declared.

\section{Cartographie de la recherche concernant les soins infirmiers et obstétricaux dans la Région de la Méditerranée orientale, 2006-2016 \\ Résumé}

Contexte : Les infirmières et les sages-femmes constituent le groupe de professionnels de santé le plus important à l'échelle mondiale. Les problèmes auxquels font face ces professions compliquent la définition de priorités au niveau régional en matière de développement de politiques et d'axes de recherche.

Objectif : L'objectif de la présente étude était de recenser les travaux de recherche actuels au regard des soins infirmiers et obstétricaux dans la Région de la Méditerranée orientale.

Méthodes : La liste des écoles d'infirmières et de sages-femmes a été dressée par l'intermédiaire de l'ordre des infirmières et des sages-femmes, et des ministères de l'éducation et de la santé publique de chaque pays. Les informations ont été recueillies pour les années 2006-2016 à l'aide d'enquêtes, via des sites Web, la base de données Google Scholar et grâce à des informateurs experts.

Résultats : Un total de 299 écoles a été recensé, 241 d'entre elles ayant été contactées ; 85 enquêtes provenant de 15 pays ont été analysées. Au total, 1116 thèmes de recherche traités dans 3287 publications ont été dénombrés, beaucoup se concentrant autour des cinq domaines prioritaires de l'Organisation mondiale de la Santé. Les domaines de recherche les moins développés étaient la gestion des catastrophes et la préparation aux situations d'urgence.

Conclusions : La présente étude fournit une base de données des travaux de recherche portant sur les soins infirmiers et obstétricaux dans la Région. Certaines lacunes par rapport aux priorités de recherche de la Région ont été relevées ; elles pourraient cependant être comblées grâce à une collaboration étroite entre les chercheurs locaux. 


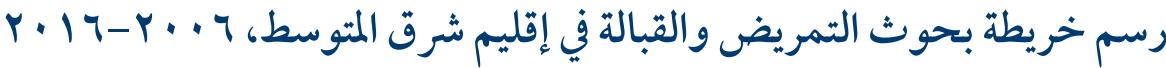 هدى أبو سعد هاير، هبة الديك، سمر نور الدين}

$$
\begin{aligned}
& \text { الخلفية: تشكل الممرضات والقابلات أكبر بجموعات المهنيين في الرعاية الصحية على الصعيد العالمي. تؤدي التحديات التي تواجه هذه المهن إلى إلى }
\end{aligned}
$$

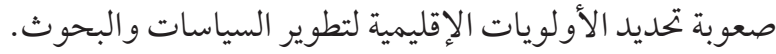

$$
\begin{aligned}
& \text { الهدف: الغرض من هذه الدراسة رسم خريطة البحوث التي تجرى حاليًا في ججال التمريض و القبالة في إقليم شرق المتوسط. } \\
& \text { طرق البحث: حددت جالس التمريض والقبالة ووزارات التعليم/ الصحة العامة في كل بلد مدارس/كليات التمريض والقبالة. وقوقد جمعنا }
\end{aligned}
$$

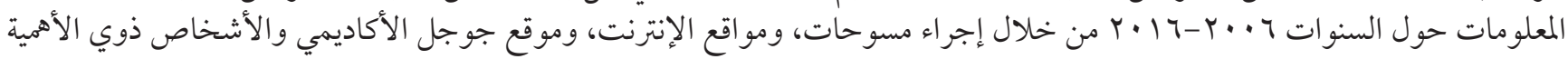

$$
\begin{aligned}
& \text { كمصادر للمعلومات. }
\end{aligned}
$$

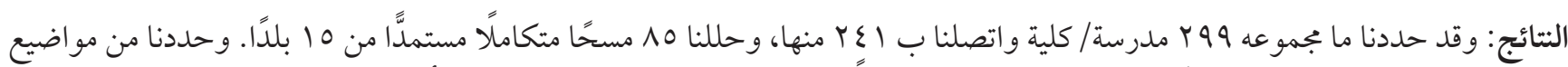

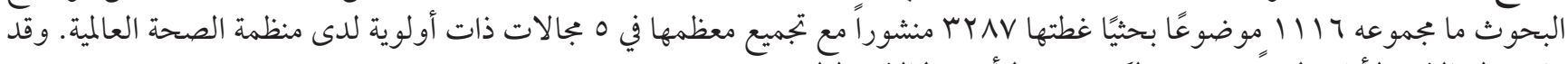

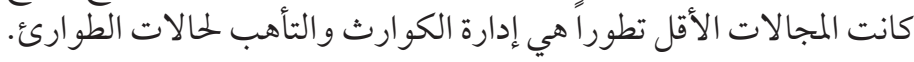

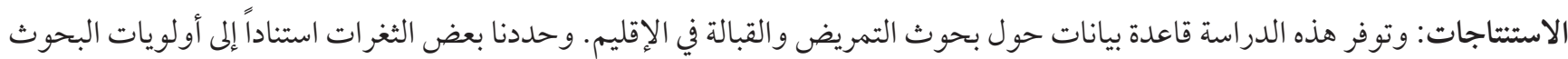

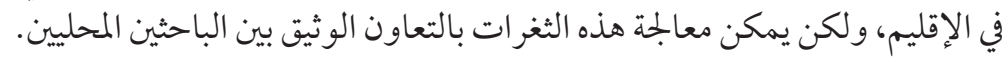

\section{References}

1. Enhancing nursing and midwifery capacity to contribute to the prevention, treatment and management of noncommunicable diseases Geneva: World Health Organization, Human Resources for Health Observer; 2012 (Issue 12; http://www.who.int/hrh/ resources/observer12.pdf, accessed 9 April 2018).

2. Nursing and midwifery. Geneva: World Health Organization; 2015. (http://www.emro.who.int/health-topics/nursing-and-midwifery/index.html, accessed 9 April 2018).

3. Al Darazi F. Nursing research priorities in the Eastern Mediterranean Region. Paper presented at the Hariri School of Nursing Research Conference and Chartering Ceremony of the Chi Iota Chapter of Sigma Theta Tau International, Beirut, 12-13 September 2014. Beirut: American University of Beirut, Hariri School of Nursing; 2014 (https://website.aub.edu.lb/hson/schoolfacts/Documents/Annual_Reports/2014.pdf, accessed 30 April 2018).

4. Health workforce and services. Geneva: World Health Organization; 2015 (EB138/36; http://apps.who.int/gb/ebwha/pdf_files/ EB138/B138_36-en.pdf, accessed 9 April 2018).

5. Mokdad AH, Jaber S, Aziz MIA, AlBuhairan F, AlGhaithi A, AlHamad NM, et al. The state of health in the Arab world, 1990-2010: an analysis of the burden of diseases, injuries, and risk factors. Lancet. 2014 Jan 25;383(9914):309-20. https://doi.org/10.1016/ So140-6736(13)62189-3 PMID:24452042

6. Nursing, midwifery and allied health personnel. Geneva: World Health Organization; 2015 (http://www.emro.who.int/nursing/ about/, accessed 9 April 2018).

7. Global strategic directions for strengthening nursing and midwifery 2016-2020 Geneva: World Health Organization; 2016 (http://www.who.int/hrh/nursing_midwifery/global-strategic-midwifery2016-2020.pdf?ua=1, accessed 9 April 2018).

8. Farsi Z, Dehghan-Nayeri N, Negarandeh R, Broomand S. Nursing profession in Iran: an overview of opportunities and challenges. Jpn J Nurs Sci. 2010 Jun;7(1):9-18. https://doi.org/10.1111/j.1742-7924.2010.00137.x PMID:20618672

9. Aldossary A, While A, Barriball L. Health care and nursing in Saudi Arabia. Int Nurs Rev. 2008 Mar;55(1):125-8. https://doi. org/10.1111/j.1466-7657.2007.00596.x PMID:18275546

10. El-Jardali F, Makhoul J, Jamal D, Ranson MK, Kronfol NM, Tchaghchagian V. Eliciting policymakers' and stakeholders' opinions to help shape health system research priorities in the Middle East and North Africa region. Health Policy Plan. 2010 Jan;25(1):1527. https://doi.org/10.1093/heapol/czp059 PMID:19948770

11. Oweis AI. Bringing the professional challenges for nursing in Jordan to light. Int J Nurs Pract. 2005 Dec;11(6):244-9. https://doi. org/10.1111/j.1440-172X.2005.00536.x PMID:16255735

12. Regional nursing forum: the future of nursing and midwifery in the Eastern Mediterranean Region. Cairo: World Health Organization Regional Office for the Eastern Mediterranean; 2015 (WHO-EM/NUR/426/E; http://applications.emro.who.int/docs/ IC_Meet_Rep_2015_EN_16403.pdf?ua=1, accessed 9 April 2018).

13. Expanded meeting for members of the advisory committee on health research and research experts to discuss integrating research in shaping the future of health in the Eastern Mediterranean Region. Cairo: World Health Organization Regional Office for the Eastern Mediterranean; 2014 (WHO-EM/RPC/033/E; http://applications.emro.who.int/docs/IC_Meet_Rep_2014_EN_15356. pdf, accessed 9 April 2018). 
14. A strategy for nursing and midwifery development in the Eastern Mediterranean Region. Cairo: World Health Organization Regional Office for the Eastern Mediterranean; 1997. (Technical Publication Series 25; http://applications.emro.who.int/dsaf/dsa22. pdf?ua=1, accessed 9 April 2018).

15. Raising the profile of nursing and midwifery in the Eastern Mediterranean Region. The need to involve nurses. East Mediterr Health J. 2015;21(9):698-9 (http://www.emro.who.int/emhj-volume-21-2015/volume-21-issue-9/raising-the-profile-of-nursing-and-midwifery-in-the-eastern-mediterranean-region.html, accessed 9 April 2018).

16. Research policy and development. Cairo: World Health Organization Regional Office for the Eastern Mediterranean; 2015 (http:// www.emro.who.int/rpc/about/, accessed 9 April 2018).

17. Mehrdad R. Health system in Iran. Japan Med Assoc J. 2009;52(1): 69-73.

18. Chapman H, Lewis P, Osborne Y, Gray G. An action research approach for the professional development of Vietnamese nurse educators. Nurse Educ Today. 2013 Feb;33(2):129-32. https://doi.org/10.1016/j.nedt.2011.11.010 PMID:22138354

19. Alhusaini MA, Sun CJ, Larson EL. Clinical nursing and midwifery research in Middle Eastern and North African countries: A Scoping review. Journal of Health Specialties. 2016;4(4):238. https://doi.org/10.4103/2468-6360.191904

20. Yaktin US, Azoury NB, Doumit MA. Personal characteristics and job satisfaction among nurses in Lebanon. J Nurs Adm. 2003 Jul-Aug;33(7-8):384-90. https://doi.org/10.1097/00005110-200307000-00006 PMID:12909789

21. Mrayyan MT. Jordanian nurses' job satisfaction, patients' satisfaction and quality of nursing care. Int Nurs Rev. 2006 Sep;53(3):224-30. https://doi.org/10.1111/j.1466-7657.2006.00439.x PMID:16879186

22. Sun C, Dohrn J, Oweis A, Huijer HAS, Abu-Moghli F, Dawani H, et al. Delphi Survey of Clinical Nursing and Midwifery Research Priorities in the Eastern Mediterranean Region. J Nurs Scholarsh. 2017 Mar;49(2):223-35. https://doi.org/10.1111/jnu.12280 PMID:28178398 